\title{
Evaluation of Oat Hull Hemicellulosic Hydrolysate Fermentability Employing Pichia stipitis
}

\author{
Luciana Cristina Silveira Chaud*, Débora Danielle Virgínio da Silva, Rafael Taino de \\ Mattos and Maria das Graças de Almeida Felipe \\ Departamento de Biotecnologia; Escola de Engenharia de Lorena; Universidade de São Paulo; Estrada Municipal \\ do Campinho, s/n; C. P.: 116; 12602-810; Lorena - SP - Brasil
}

\begin{abstract}
Oat hull hemicellulosic hydrolysate obtained by diluted acid hydrolysis was employed as fermentation medium for Pichia stipitis cultivation. A comparison between the use of treated hydrolysate with $1 \%$ activated charcoal to reduce the toxic compounds generated during the hydrolysis process and untreated hydrolysate as a control was conducted. In the cultures using treated hydrolysate the total consumption of glucose, low xylose consumption and ethanol and glycerol formation were observed. The medium formulated with untreated hydrolysate showed morphological cell modifications with consequently cell death, no ethanol formation and formation of glycerol as byproduct of fermentative process, probably as a response to stressful conditions to yeast due to presence of high concentration of toxic compounds. Thus, further studies are suggested in order to determine the best conditions for hydrolysis and detoxification of the hydrolysate to improve the fermentative performance of $\mathrm{P}$. stipitis.
\end{abstract}

Key words: Pichia stipitis, hemicellulosic hydrolysate, oat hull, ethanol, activated charcoal

\section{INTRODUCTION}

The growing interest in the biotechnological use of byproducts generated by the agribusiness have been based on the premises of environmental conservation, low-cost feedstock and obtaining products of high added value through controlled processes.

In this context, new investigations in biotechnology have a fundamental importance to determine the behavior of microorganism grown on plant biomass, in solid form (Pinto 2007) or in cellulosic and hemicellulosic hydrolysates (Felipe et al. 1997; Mussato and Roberto 2002; Canilha et al. 2003; Tamanini et al. 2004; Marton et al. 2006; Jeon et al. 2010).

Oats, cereal member of the genus Avena, is a grass
(Ceres 2011) with multiple possibilities for use as food, feed, forage, cover soil and green manure, besides the inhibition of weed infestations (Sá 1995). In Brazil, the estimated production for the $2010 / 2011$ crop is about 379,000 tons of oat grains (Conab 2011).

The oat hull, a byproduct of grain milling, is equivalent to about $25-30 \%$ of grain weight (Wang and Klopfenstein 1993), whose main function is maintaining the grains clean and protected from mechanical destruction and pathogen attacks. This byproduct has traditionally been discarded and becoming a pollutant to the environment, although it can be utilized for the production of industrial solvents, sweeteners and animal feed, as well in food industry, in the production of breads, crackers and pasta (Galdeano 2006; GonzálezAlvarado et al. 2010).

*Author for correspondence: lu_chaud@debiq.eel.usp.br 
According to Tamanini et al. (2004), oat hulls are composed of cellulose $(29.26 \%)$, hemicellulose (28.35\%) and lignin (22.22\%), among others. Due to the high sugar content in the hemicellulose fraction of oat hulls, it may also be used in the bioprocesses to produce the products of high added value, such as ethanol (Lawford et al. 2001) and xylitol (Tamanini et al. 2004).

However, during diluted acid hydrolysis process, usually employed for the deconstruction of the hemicellulosic polysaccharides into fermentable sugars (D-xylose, D-glucose, L-arabinose), toxic compounds to microorganisms (acetic acid, phenolic compounds, furfural and hydroxymethylfurfural) are also generated that inhibit the microbial activity (Felipe et al. 1995; Palmqvist and Hahn-Hägerdal 2000; Felipe 2004; Silva et al. 2004; Diaz et al. 2009). According to Tamanini et al. (2004), oat hull hemicellulosic hydrolysate presents high concentrations of toxic compounds. Thus, it is essential to treat the hydrolysate before using it in fermentation medium.

Different detoxification procedures have been evaluated to remove or reduce the toxic compounds concentrations such as $\mathrm{pH}$ adjustment combined with activated charcoal adsorption (Marton et al. 2006), adsorption onto ion-exchange resins (Canilha et al. 2010) and utilization of plant polymer ( Chaud 2010). The use of $1 \%$ activated charcoal has been shown an effective and inexpensive alternative in the detoxification of hemicellulosic hydrolysates (Silva et al. 2007).

Due to heterogeneous composition of the hemicellulosic hydrolysates, it is necessary to screen for an efficient microorganism able to ferment a variety of sugars (pentoses, and hexoses) as well as to tolerate stress conditions, in order to optimize the production of the product of interest (Zaldivar et al. 2001).

Among the xylose-fermenting yeasts, Pichia stipitis has been considered promising for industrial applications due to its ability to ferment xylose with a high ethanol yield (Agbogbo et al. 2006). In this context, the aim of this work was to evaluate the fermentative performance of Pichia stipitis cultivated in treated or untreated oat hull hemicellulosic hydrolysate.

\section{MATERIAL AND METHODS}

\section{Microorganisms and inoculum preparation}

The experiments were conducted with $P$. stipitis NRRL Y-7124 maintained at $4^{\circ} \mathrm{C}$ on malt-extract agar slants. A loopful of cells grown on a maltextract agar slant was transferred to the medium used for inoculum preparation containing xylose $(30.0 \mathrm{~g} / \mathrm{L})$, rice bran extract $(20.0 \mathrm{~g} / \mathrm{L}),\left(\mathrm{NH}_{4}\right)_{2} \mathrm{SO}_{4}$ $(2.0 \mathrm{~g} / \mathrm{L})$ and $\mathrm{CaCl}_{2} \cdot 2 \mathrm{H}_{2} \mathrm{O}(0.1 \mathrm{~g} / \mathrm{L})$. Erlenmeyer flasks $(125 \mathrm{ml})$, each containing $50 \mathrm{~mL}$ medium, were incubated on a rotary shaker (200rpm) at $30^{\circ} \mathrm{C}$ for $24 \mathrm{~h}$. Afterwards, the cells were separated by centrifugation $(2000 \mathrm{xg} ; 20 \mathrm{~min})$, rinsed twice with distilled water, and then the cell pellet was once again suspended in an adequate volume of distilled water. The initial cell concentration for all the experiments was around $1.0 \mathrm{~g} / \mathrm{L}$.

\section{Diluted acid hydrolysis and treatment of oat hull hemicellulosic hydrolysate}

Oat hull was hydrolysed in a $1 \mathrm{~L}$ steel reactor at $156^{\circ} \mathrm{C}$ for 27 min with $\mathrm{H}_{2} \mathrm{SO}_{4}(0.35 \%$, w/v $)$ at 1:4.5 solid/liquid ratio (Canettieri et al. 2001). Afterwards, its $\mathrm{pH}$ was initially adjusted to 7.0 with $\mathrm{CaO}$ (commercial grade) and then to 2.5 with $\mathrm{H}_{3} \mathrm{PO}_{4}$, followed by the addition of $1.0 \%$ (w/v) activated charcoal (refined powder), for $30 \mathrm{~min}$, under agitation $\left(200 \mathrm{rpm}, 60{ }^{\circ} \mathrm{C}\right)$. The precipitate formed as a result of this treatment was removed by vacuum filtration (Silva et al. 2007). The untreated hydrolysate also was used in the experiments and its $\mathrm{pH}$ was adjusted to 5.5 with $\mathrm{NaOH}$. The hydrolysates were autoclaved at $111^{\circ} \mathrm{C}$, under $0.5 \mathrm{~atm}$.

\section{Medium and fermentation conditions}

For fermentation media preparation, the treated and untreated hydrolysates were supplemented with $(\mathrm{g} / \mathrm{L})$ : rice bran extract 20.0, $\left(\mathrm{NH}_{4}\right)_{2} \mathrm{SO}_{4} 2.0$ and $\mathrm{CaCl}_{2} \cdot 2 \mathrm{H}_{2} \mathrm{O}$ 0.1. The media $(50 \mathrm{~mL})$ were placed in Erlenmeyer flasks $(125 \mathrm{ml})$ and incubated at $30^{\circ} \mathrm{C}$ and $200 \mathrm{rpm}$ for $72 \mathrm{~h}$ ( Silva et al. 2010), with initial $\mathrm{pH}$ adjusted to 5.5 (Sun et al. 2011). The experiments were conducted in duplicate.

\section{Analytical methods \\ Xylose, glucose, arabinose, xylitol, ethanol, glycerol, acetic acid, furfural and hydroxymethylfurfural concentrations were determined by HPLC (Waters, Milford, MA) with}


a refraction index detector on a Bio-Rad Aminex $\mathrm{HPX}-87 \mathrm{H}$ at $45^{\circ} \mathrm{C}$, with $0.01 \mathrm{~N} \mathrm{H}_{2} \mathrm{SO}_{4}$ as the eluent at $0.6 \mathrm{~mL} / \mathrm{min}$ flow rate. A Hewlett-Packard RP 18 column at $25^{\circ} \mathrm{C}$ with acetonitrile:water (1:8) and $1 \%$ acetic acid as the eluent, and a $0.8 \mathrm{~mL} / \mathrm{min}$ flow rate was employed for determination of furfural concentration in a visible ultraviolet-light detector (SPD-10 ${ }^{\mathrm{A}}$ UV-VIS). The total phenolic compounds concentration was estimated by the ultraviolet spectroscopy at $280 \mathrm{~nm}$ (Gouveia et al. 2009). The concentrations of metallic ions were determined by the flame atomic-absorption spectroscopy as described by Soares et al. (2010).

Cell growth was monitored by measuring the absorbance at $600 \mathrm{~nm}$ (Beckman-DU 640B spectrophotometer). The cell concentration was calculated based on the on the relation of optical density and cell dry weight through a calibration curve. Cell number was determined directly by counting in a NEUBAUER chamber (area $=1 / 400 \mathrm{~mm}^{2}$; height $\left.=0.100 \mathrm{~mm}\right)$.

\section{RESULTS AND DISCUSSIONS}

Oat hull hemicellulosic hydrolysate composition Table 1 presents the contents of sugars, toxic compounds and metallic ions in the oat hull hemicellulosic hydrolysate before and after the toxic compounds with the treatment using $1 \%$ charcoal, except in the case of the acetic acid, whose concentration remained almost unchanged. However, the treatment also resulted in the loss of about $20 \%$ of sugars, which was totally undesirable.

Table 1 - Characteristics of oat hull hemicellulosic hydrolysate before and after treatment process.

\begin{tabular}{lccc}
\hline \multicolumn{1}{c}{ Components } & Original Hydrolysate & Treated Hydrolysate & $\begin{array}{c}\text { Not Treated } \\
\text { Hydrolysate }\end{array}$ \\
\hline Sugars $(\mathrm{g} / \mathrm{L})$ & & & \\
Xylose & 58.56 & 46.80 & 53.02 \\
Glucose & 11.48 & 8.32 & 10.36 \\
Arabinose & 8.00 & 6.44 & 7.68 \\
Toxic Compounds $(\mathrm{g} / \mathrm{L})$ & & & \\
Acetic Acid & 5.40 & 5.10 & 5.40 \\
Total Phenols & 2.50 & 1.19 & 2.50 \\
Furfural & 1.19 & 0.48 & 0.92 \\
Hydroxymethylfurfural & 0.32 & 0.20 & 0.26 \\
Inorganics $(\mathrm{mg} / \mathrm{L})$ & & & \\
$\mathrm{Na}$ & 52.40 & 6948.70 & 6896.20 \\
$\mathrm{~K}$ & 1677.00 & 1.25 & 1575.00 \\
$\mathrm{Mg}$ & 318.20 & 299.80 & 328.60 \\
$\mathrm{Ca}$ & 187.30 & 79.62 & 199.30 \\
$\mathrm{Cr}$ & $\mathrm{nd}$ & $\mathrm{nd}$ & $\mathrm{nd}$ \\
$\mathrm{Mn}$ & $\mathrm{nd}$ & $\mathrm{nd}$ & $\mathrm{nd}$ \\
$\mathrm{Fe}$ & 43.10 & 2.82 & 32.50 \\
$\mathrm{Ni}$ & 4.20 & 10.05 & 13.20 \\
$\mathrm{Zn}$ & $\mathrm{nd}$ & nd & nd \\
\hline $\mathrm{nd}$ not detected & & & *hydrolysate with pH adjustment
\end{tabular}

According to Palmqvist and Hahn-Hägerdal (2000), the presence of toxic compounds can impair cellular metabolism, either by acidifying the cytosol, such as acetic acid or the loss of membrane biological integrity, like the phenolic compounds and furans, furfural and hydroxymethylfurfural, which can inhibit the microbial activity at low concentrations.

A reduction was also observed in the metallic ions concentrations: $\mathrm{Mg}$ (5.78\%), $\mathrm{Ca}$ (20\%), $\mathrm{Fe}$
(93.4\%) and $\mathrm{K}(99.9 \%)$, while the concentrations of $\mathrm{Na}$ and $\mathrm{Ni}$ increased in the treated and untreated hydrolysates (Table 1). This probably occurred due to $\mathrm{NaOH}$ used to adjust the $\mathrm{pH}$ of the hydrolysates before its use as fermentation media. The increase in Ni concentration could be related to the equipment used for the homogenization of the hydrolysate during the treatment process and $\mathrm{pH}$ adjustment. The removal of metallic ions and phenolic compounds employing the activated 
charcoal was also observed by Mussato et al. (2010) in brewer's spent grain hemicellulosic hydrolysate.

It has been reported that many metals influence positively the yeast fermentation performance as they are required for the growth and metabolism. Besides, yeasts are able to very effectively accumulate essential minerals and exclude or detoxify the non-essential minerals (Walker et al. 2006). Some metal ions (K, Na, Zn) can change the rate of glycolysis and subsequently the conversion of pyruvate to ethanol. Metal ions are vital for all the organisms, as they play an important role in the cellular metabolism primarily due to their requirements as cofactors for a large number of enzymes (Soares et al. 2003). However, the presence of these compounds in the toxic concentrations can be a significant problem during the fermentation of various substrates into useful chemical products (Tosun and Ergun 2007).

For example, sodium ion concentration has significant effect on ethanol production by $S$. cerevisiae, and there is interactive effect only between calcium and magnesium in complex media (Soyuduru et al. 2009). Thus, further studies should be made on the effect of ions concentration on the P. stipitis metabolism.

\section{Fermentation of oat hull hemicellulosic hydrolysate}

Figure 1A shows the sugars consumption by $P$. sitipis grown in oat hull hemicellulosic hydrolysates.

The use of untreated hydrolysate resulted in the consumption of only $4 \%$ of glucose and $2.15 \%$ of xylose after $72 \mathrm{~h}$ of fermentation. The use of the treated hydrolysate, resulted a total consumption of glucose and $16.79 \%$ of xylose after 48 and $72 \mathrm{~h}$ of fermentation, respectively (Fig. 1A). Arabinose was not assimilated by the yeast, regardless of conditions employed. Thus, the use of treated hydrolysate resulted in the consumption of xylose and glucose, 8 -fold and 25-fold higher respectively than that observed with untreated hydrolysate.
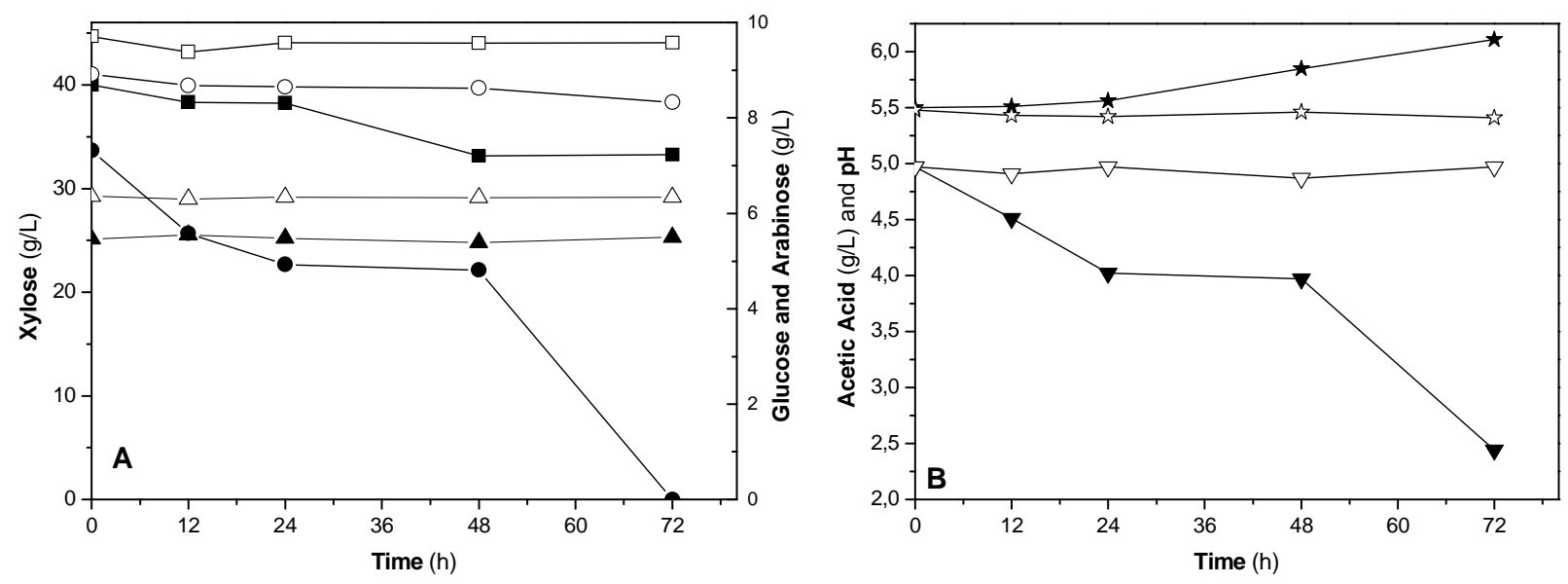

Figure 1 - (A) Consumption of xylose (square), glucose (circle) and arabinose (up triangle); (B) acetic acid (down triangle) and $\mathrm{pH}$ variation (star) by P. stipitis grown in oat hull hemicellulosic hydrolysate treated (black symbol) or not (white symbol) with $1 \%$ activated charcoal.

It is important to note that even in the treated hydrolysate, sugar consumption was very low, probably due to the toxic compounds present in concentrations considered inhibitory to yeast metabolism. In both the hydrolysates, acetic acid concentration was higher than $5 \mathrm{~g} / \mathrm{L}$. It is known that acetic acid in concentrations higher than $3 \mathrm{~g} / \mathrm{L}$ can inhibit xylose metabolism (Felipe et al. 1995). Besides this, the concentrations of furfural, 5-
HMF and phenols were also high. According to Diaz et al. (2009), inhibitory compounds can affect the fermentation performance by $P$. stipitis in a synergistic way. They found that in the experiments performed with $P$. stipitis grown in the synthetic medium containing $20 \mathrm{~g} / \mathrm{L}$ glucose and $15 \mathrm{~g} / \mathrm{L}$ xylose in the presence of $2 \mathrm{~g} / \mathrm{L}$ furfural and $3 \mathrm{~g} / \mathrm{L}$ acetic acid, no sugar consumption was 
detected and cellular growth was completely inhibited.

Decrease in acetic acid concentration was also observed in this work when treated hydrolysate was employed as fermentation medium and was accomplished by raising the medium $\mathrm{pH}$ (Fig. 2B).
In the cultures with untreated hydrolysate neither acetic acid consumption nor change in $\mathrm{pH}$ was observed.

The low assimilation of sugars by $P$. stipitis appeared be directly related to low cell growth as shown in Figure 2.

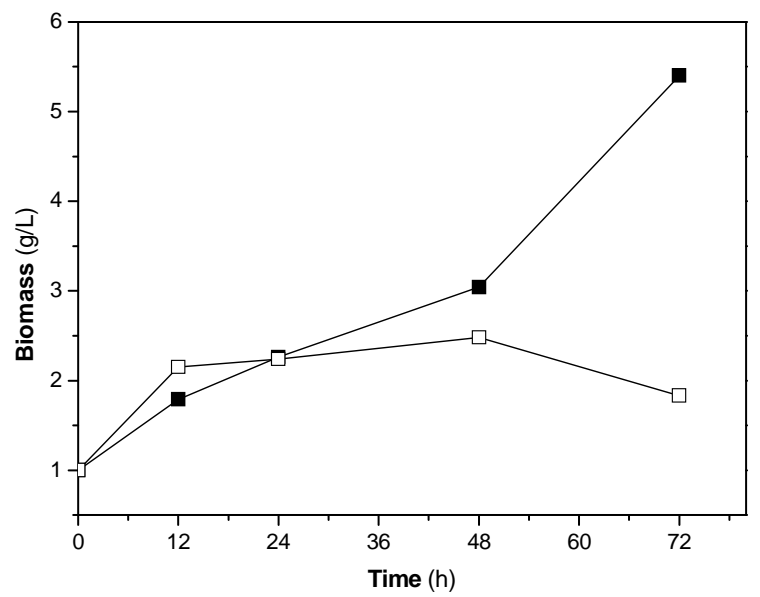

Figure 2 - Cell growth during P. stipitis fermentation on oat hull hemicellulosic hydrolysate treated (black symbol) or not (white symbol) with $1 \%$ activated charcoal.

The fermentation medium formulated with untreated oat hull hemicellulosic hydrolysate resulted in lower cell growth (54\%) compared with the treated hydrolysate. Besides, the use of untreated hydrolysate resulted in the morphological changes in yeast cells (data not showed), with consequently cell death after $48 \mathrm{~h}$ of fermentation, which was not the case with the use of the treated hydrolysate, even with the partial removal of toxic compounds.

Figure 3 shows the formation of ethanol and glycerol during the fermentation of oat hull hemicellulosic hydrolysate by $P$. stipitis.

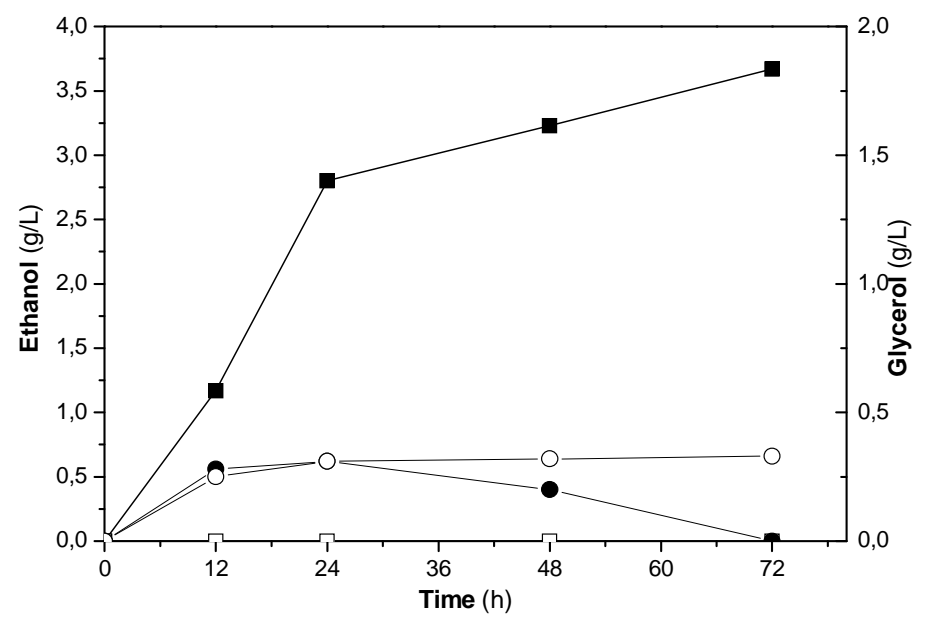

Figure 3 - Ethanol (square) and glycerol (circle) formation by P. stipitis grown on oat hull hemicellulosic hydrolysate treated (black symbol) or not (white symbol) with $1 \%$ activated charcoal. 
The high concentration of toxic compounds resulted in low sugar consumption by the yeast (Fig. 1A) and consequently also resulted in low ethanol production (Fig. 3). Ethanol formation was observed only by employing the medium formulated with the treated hydrolysate. In this condition, maximum ethanol formation $(3.67 \mathrm{~g} / \mathrm{L})$ was close to that reported by Klinner et al. (2005) in the study with $P$. stipitis in the synthetic medium containing only glucose $(30 \mathrm{~g} / \mathrm{L})$ as carbon source (ethanol around $5.0 \mathrm{~g} / \mathrm{L}$ ) and considerably lower than that reported by Agbogbo et al. (2006), with the same yeast grown in a synthetic medium containing glucose $(30 \mathrm{~g} / \mathrm{L})$ and xylose $(30 \mathrm{~g} / \mathrm{L})$ (ethanol $23 \mathrm{~g} / \mathrm{L}$ ) and that observed by Nigam (2001) in wheat straw hemicellulosic hydrolysate with xylose $(30 \mathrm{~g} / \mathrm{l})$ and glucose $(3 \mathrm{~g} / \mathrm{L})$ (ethanol $15 \mathrm{~g} / \mathrm{L})$.

The low ethanol production employing the treated hydrolysate and no formation in untreated hydrolysate together with the formation of byproduct glycerol (Fig. 3) were directly related to high concentrations of toxic compounds in the hydrolysate. The formation of glycerol, a compatible solute has been observed as a response to stressful conditions in yeast, imposed by the toxic compounds present in the hemicellulosic hydrolysates (Arruda and Felipe 2009).

\section{CONCLUSIONS}

The current work showed the fermentative performance of $P$. stipitis cultivated on oat hull hemicellulosic hydrolysate. The yeast was able to grow using the sugars of the hydrolysate with consequent production of ethanol and also glycerol as the by-product. Due to the high concentration of toxic compounds to microbial metabolism present in the hydrolysate, the production of ethanol was very low. To improve the fermentative performance of $P$. stipitis on oat hull hemicellulosic hydrolysed, further studies should be done to improve the hydrolysis and detoxification processes. Besides, it is necessary to evaluate an adequate supplementation of nutrients and also methods for cell adaptation to toxic compounds in order to increase ethanol production.

\section{REFERENCES}

Agbogbo FK, Coward-Kelly G, Torry-Smith M, Wenger KS. Fermentation of glucose/xylose mixtures using Pichia stipitis. Process Biochem. 2006; 41: 2333-2336.

Arruda PV, Felipe MGA. Role of glycerol addition on xylose-to-xylitol bioconversion by Candida guilliermondii. Curr Microbiol. 2009; 58: 274-278.

Canettieri EV, Almeida e Silva JB, Felipe MGA. Application on factorial design for xylitol production from eucalyptus hemicellulosic hydrolysate. Appl Biochem Biotechnol. 2001; 94: 159-168.

Canilha L, Almeida e Silva JB, Felipe MGA, Carvalho W. Batch xylitol production from wheat straw hemicellulosic hydrolysate using Candida guilliermondii in a stirred tank reactor. Biotechnol Lett. 2003; 25: 1811-1814.

Ceres on line [homepage on the internet]. Florianópolis: Laboratório de Ciência e Tecnologia de Cereais, Centro de Ciências Agrárias, UFSC; [acessed in 2011 Sep. 12]. Available from: http://www.cca.ufsc.br/dcal/labs/ceres/aveia.html.

Chaud LCS. Avaliação do carvão vegetal ativado e polímero vegetal na destoxificação do hidrolisado hemicelulósico de bagaço de cana-de-açúcar para a produção biotecnológica de xilitol. MSc Dissertation. Lorena, Brazil: Escola de Engenharia de Lorena; 2010.

Conab on line. Acompanhamento da safra brasileira. Grãos: 2010/2011 [homepage on the internet]. Brasília: Companhia Nacional de Abastecimento; [acessed in 2011 March 03]. Available from: http://www.conab.gov.br/OlalaCMS/uploads/arquivo

Diaz MJ, Ruiz E, Romero I, Cara C, Moya M, Castro E. Inhibition of Pichia stipitis fermentation of hydrolysates from olive tree cuttings. World $J$ Microbiol Biotechnol. 2009; 25: 891-899.

Felipe MGA. Biotechnological production of xylitol from lignocellulosic materials. In: B Saha and K Hayoshi, editors. Advances in Biodegradation and biotransformation lignocelulosics. New York: American Chemical Society; 2004. p. 300-317.

Felipe MGA, Vitolo M, Mancilha IM, Silva SS. Fermentation of sugar cane bagasse hemicellulosic hydrolysate for xylitol production: effect of $\mathrm{pH}$. Biomass and Bioenergy. 1997; 13: 11-14.

Felipe MGA, Vieira DC, Vitolo M, Silva SS, Roberto IC, Mancilha IM. Effect of acetic acid on xylose fermentation to xylitol by Candida guilliermondii, $J$ Basic Microbiol. 1995; 35: 171-177.

Galdeano MC, Grossmann MVE. Oat hulls treated with alkaline hydrogen peroxide associated with extrusion as fiber source in cookies. Ciência e Tecnologia de Alimentos. 2006; 26 (1): 123-126. 
González-Alvarado JM, Jiménez-Moreno E, GonzálezSanches D, Lázaro R, Mateos GG. Effect of inclusion of oat hulls and sugar beet pulp in the diet on productive performance and digestive traits of broilers from 1 to 42 days of age. Anim Feed Sci Technol. 2010; 162 (1-2): 37-46.

Gouveia ER, Nascimento RT, Souto-Maior AM. Validação de metodologia para a caracterização química de bagaço de cana-de-açúcar. Quim Nova. 2009; 32 (6): 1500-1503.

Jeon YJ, Xun Z, Rogers PL. Comparative evaluations of cellulosic raw materials for second generation bioethanol production. Lett Appl Microbiol. 2010; 51: 518-524.

Klinner U, Fluthgraf S, Freese S, Passoth V. Aerobic induction of respiro-fermentative growth by decreasing oxygen tensions in the respiratory yeast Pichia stipitis. Appl Microbiol Biotechnol. 2005; 67: 247-253.

Lawford HG, Rousseau JD, Tolan JS. Comparative ethanol productivities of different Zymomonas recombinants fermenting oat hull hydrolysate. Appl Biochem Biotechnol. 2001; 91-93: 133-146.

Marton JM, Felipe MGA, Almeida e Silva JB, Pessoa Júnior A. Evaluation of the activated charcoals and adsorption conditions used in the treatment of sugarcane bagasse hydrolysate for xylitol production. Braz J Chem Eng. 2006; 23 (01): 9-21.

Mussatto SI, Fernandes M, Rocha GJM, Órfão JJM, Teixeira JA, Roberto IC. Production, characterization and application of activated carbon from brewer's spent grain lignin. Biores Technol. 2010; 101: 24502457.

Mussatto SI, Roberto IC. Produção biotecnológica de xilitol a partir da palha de arroz. Biotecnol Ciênc Desenvolv. 2002; 28: 34-39.

Nigam JN. Development of xylose-fermenting yeast Pichia stipitis for ethanol production through adaptation on hardwood hemicellulose acid prehydrolysate. J Appl Microbiol. 2001; 90: 208-215.

Palmqvist E, Hahn-Hägerdal B. Fermentation of lignocellulosic hydrolyzates. II: inhibitors and mechanisms of inhibition. Biores Technol. 2000; 74: 25-33.

Pinto SAG, Brito ES, Andrade AMR, Fraga SLP, Teixeira RB. Fermentação em estado sólido: uma alternativa para o aproveitamento e valorização de resíduos agroindustriais tropicais [homepage on the internet]. Brasília: Embrapa; updated in 2007 Oct.; [acessed in 2011 Jul. 05]. Available from: http://www.cnpat.embrapa.br/cnpat/cd/jss/acervo/

Sá JPG. Utilização da aveia na alimentação animal. Londrina: IAPAR; updated in 1995; [ acessed in 2011 Apr. 11]. Available from: http://www.iapar.br/arquivos/File/zip_pdf/ctutilaveia

Silva DDV, Mancilha IM, Silva SS, Felipe MGA. Improvement of biotechnological xylitol production by glucose during cultive of Candida guilliermondii in sugarcane bagasse hydrolysate, Braz Arch Biol Technol. 2007; 50 (2):, 207-215.

Silva DDV, Felipe MGA, Mancilha IM, Luchese RH, Silva SS. Inhibitory effect of acetic acid on bioconversion of xylose in xylitol by Candida guilliermondii in sugarcane bagasse hydrolysate. Braz J Microbiol. 2004; 35: 248-254.

Silva JPA, Mussato SI, Roberto IC. The influence of initial xylose concentration, agitation, and aeration on ethanol production by Pichia stipitis from rice straw hemicellulosic hydrolysate. Appl Bioch Biotechnol. 2010; 162 (5): 1306-1315.

Soares VA, Kus MMM, Peixoto ALC, Carrocci JS, Salazar RFS, Izário Filho HJ. Determination of nutritional and toxic elements in pasteurized bovine milk from Vale do Paraiba region (Brazil). Food Control. 2010; 21: 45-49.

Soares EV, Hebbelinck K, Soares HMVM. Toxic effects caused by heavy metals in the yeast Saccharomyces cerevisiae: a comparative study. Can J Microbiol. 2003; 49: 336-343.

Soyuduru D, Ergun M, Tosun A. Application of a Statistical Technique to Investigate Calcium, Sodium, and Magnesium Ion Effect in Yeast Fermentation. Appl Biochem Biotechnol. 2009; 152: 326-333.

Sun Z, Shupe A, Liu T, Hu R, Amidon T, Liu S. Particle properties of sugar maple hemicellulosic hydrolysate and its influence on growth and metabolic behavior of Pichia stipitis. Biores Technol. 2011; 102: 2133-2136.

Tamanini C, Oliveira AS, Felipe MGA, Canettieri EV, Cândido EJ, Hauly COM. Avaliação da casca de aveia para produção biotecnológica de xilitol. Acta Scient Technol. 2004; 26 (2): 117-125.

Tosun A, Ergun M. Use of experimental design method to investigate metal ion effects in yeast fermentations. J Chem Technol Biotechnol.2007; 82: 11-15 .

Walker G, De Nicola R, Anthony S, Learmonth RP. Yeast-metal interactions: impact on brewing and distilling fermentations. In: Institute of Brewing and Distilling Asia Pacific Convention; 19-24 March. Hobart, Australia. 2006

Wang WM, Klopfenstein CF. Effect of twin-screw extrusion on the nutritional quality of wheat, barley and oats. Cereal Chem. 1996; 70 (6): 712-715.

Zaldivar J, Nielsen J, Olsson L. Fuel ethanol production from lignocellulose: a challenge for metabolic engineering and process integration. Appl Microbiol Biotechnol. 2001; 56: 17-34. 
Página Em

Branco 